\title{
Isolation and Screening of Protease Enzyme Producing Bacteria from Cheese at Dilla University, Ethiopia
}

\author{
Fekadu Alemu \\ Department of Biology, College of Natural and Computational Sciences, Dilla University, Dilla, Ethiopia
}

Email address:

fekealex@gmail.com

To cite this article:

Fekadu Alemu. Isolation and Screening of Protease Enzyme Producing Bacteria from Cheese at Dilla University, Ethiopia. International Journal of Nutrition and Food Sciences. Vol. 4, No. 2, 2015, pp. 234-239. doi: 10.11648/j.jinfs.20150402.25

\begin{abstract}
Enzymes are biological catalysts that facilitate the conversion of substrates into products by providing favorable conditions that lower the activation energy of the reaction. An enzyme may be a protein or a glycoprotein and consists of at least one polypeptide moiety. Proteases are the most important industrial enzymes and comprise about $25 \%$ of commercial enzymes in the world. Two third of the industrially produced proteases are from microbial sources. The current study was focused on the screening of protease enzyme producing bacteria from dairy product of cheese at Dilla University. Cheese sample was collected from Dilla town market. The proteases enzyme production bacteria were screened on milk agar plate through spread plate method. As the result, certain bacteria were screened for protease enzyme production as well as were confirmed on milk agar medium. Almost all isolated (35 isolate) of bacteria from cheese food stuff were had a potential in the production of protease enzyme which help for various activities. Therefore, all isolate had a promising potential for production proteolytic enzyme which are used in industries and the other sectors.
\end{abstract}

Keywords: Cheese, Clear Zone, Enzyme, Proteases, Screening of Bacteria

\section{Introduction}

Proteases are a group of enzymes, whose catalytic function is to hydrolyze peptide bonds of proteins and break them down into polypeptides or free amino acids. They constitute $59 \%$ of the global market of industrial enzymes, which is expected to exceed \$ 2.9 Billion by 2012 (Deng et al., 2010). They have got wide range of commercial usage in detergents, leather, food and pharmaceutical industries (Bhaskar et al., 2007; Jellouli et al., 2009). Sources of proteases include all forms of life, that is, plants, animals and microorganisms.

Enzymes are substances present in the cells of living organisms in minute amounts and are capable of speeding up chemical reactions (associated with life processes), without themselves being altered after the reaction. They accelerate the velocity of the reaction without necessarily initiating it (Oyeleke and Oduwole, 2009). Extracellular hydrolytic enzymes such as amylases, proteases, lipases, DNases, pullulanases, and xylanases have quite diverse potential usages in different areas such as food industry, feed additive, biomedical sciences, and chemical industries (Sanchez-Porro et al., 2003). Protease refers to a group of enzymes whose catalytic function is to hydrolyze proteins. They are also called proteolytic enzymes or proteinases. Protease are the class of enzymes, which occupy key position with respect to their applications in both physiological and commercial fields. They represent one of the three largest groups of industrial enzymes and account for about $60 \%$ total worldwide sale of enzymes (Rao et al., 1998). Among all the proteases, alkaline proteases are robust in nature and are primarily used as detergent additives (Gupta et al., 2002). There is renewed interest in the study of proteolytic enzymes, mainly due to the recognition that they not only play a critical role in cellular metabolic processes but have also gained considerable attention in the industrial community. The extracellular proteases are of commercial value and find multiple applications in various industrial sectors.

Several microbial strains including fungi (Aspergillus flavus, Aspergillus miller, Aspergillus niger and Penicillium griseofulvin) and Bacterial (Bacillus licheniformis, Bacillus firmus, Bacillus alcalo Bacillus subtilis and Bacillus thuringiensis) have reported to produce proteases. Production of these biocatalyst using agro-biotech substrate under solid state fermentation and conditions provide several advantages in producing, cost effectiveness in labour, time and medium components in addition to environmental advantages like less effluent production, waste minimization (Pandey et al., 2000). 
Microbial proteases are among the most important hydrolytic enzymes and have been considered extensively since the advent of enzymology (Gupta et al., 2002). They are obtained in large quantities in a relatively short time by established microbial fermentation techniques. These are a single class of enzymes which occupy a pivotal position with respect to their applications in both physiological and commercial fields. Some extracellular enzymes are used in the food, dairy, pharmaceutical, and textile industries and are produced in large amounts by microbial synthesis (Aleksieva and Peeva, 2000; Benslimane et al., 1995). The major uses of free proteases occur in dry cleaning, detergents, meat processing, cheese making, silver recovery from photographic film, production of digestive and certain medical treatments of inflammation and virulent wounds (Nout and Rombouts, 1990).

Microbial enzymes are preferred to those from both plant and animal sources because they are inexpensive to produce, and their contents are more predictable, controllable and reliable (Burhan et al., 2003). These naturally occurring enzymes are quite often not readily available in sufficient quantities for food applications or industrial use. However, by isolating microbial strains that produce the desired enzyme and optimizing the conditions for growth, commercial quantities can be obtained. This technique, well known for more than 3,000 years, is called fermentation.

Some of the typical applications include enzyme use in the production of sweeteners, chocolate syrups, bakery products, alcoholic beverages, precooked cereals, infant foods, fish meal, cheese and dairy products, egg products, fruit juice, soft drinks, vegetable oil and puree, candy, spice and flavor extracts, and liquid coffee, as well as for dough conditioning, chill proofing of beer, flavor development, and meat tenderizing. Enzymes also play a significant role in non-food applications. Industrial enzymes are used in laundry and dishwashing detergents, stonewashing jeans, pulp and paper manufacture, leather dehairing and tanning, de-sizing of textiles, deinking of paper, and degreasing of hides (Enzyme Technical Association, 2001). It is also used to reduction of tissue inflammation (clinical and medical) application (Djamel et al., 2009). Among the various proteases, bacterial proteases exhibit most significant applications in industries when compared with plant and animal proteases. As the result, there is an increased interest in microbial proteases. Therefore, the present study was focused on the screening of protease enzyme producing bacteria from dairy product of cheese.

\section{Materials and Methods}

\subsection{Sample Collection}

Cheese was collected in sterilized sampling flask from Dilla town market. The sample was brought to Dilla University into Microbiology Laboratory. The sample was kept in the freeze at $-4^{0} \mathrm{c}$ until the experiment was conducted.

\subsection{Screening of Protease Producing Bacteria}

25 grams of cheese was taken in to $225 \mathrm{ml}$ of $0.1 \%$ of peptone of sterilized distilled water and was shakes for 15 minutes on the shaker. Subsequent dilution was made for the sample according to serial dilution technique. Then, for inoculation $0.1 \mathrm{ml}$ of the cheese dilution was taken as inoculums for spread on milk agar $(1 \mathrm{~g} / \mathrm{l}$ milk solid, $5 \mathrm{~g} / 1$ peptone, $3 \mathrm{~g} / \mathrm{l}$ yeast extract and $20 \mathrm{~g} / \mathrm{l}$ agar). After that the inoculated plates were incubated in an incubator at $30^{\circ} \mathrm{C}$ for 24-48 h. After $24-48 \mathrm{~h}$ at $30^{\circ} \mathrm{C}$, colonies which exhibited the largest cleared zones were selected and was further incubated in culture media for further $48 \mathrm{hrs}$ and checked for protease production. The isolates were screened on the basis of larger zone on milk agar medium and further confirmed. The screened isolate were re-culture for further confirmation. A total of 35 bacterial cultures were isolated. Isolated bacteria were designated as Iso1, Iso2, Iso3--------Iso35. All 35 isolated bacteria from cheese samples were screened for proteolytic activity on milk agar. At regular intervals of 24$48 \mathrm{~h}$ the activity of protease (clean zone) was measured and sample showing maximum activity was screened for protease producing bacteria.

\subsection{Biochemical Characterization of Protease Produced Isolate of Bacteria}

The bacteria which have potential for the production of protease enzyme were screened. The biochemical characterization were made for these traits pigment, gram strain $(-)$, catalase $(+)$ and oxidase $(+)$ reactions, using morphological characteristics based on Bergey's Manual of Determinative Bacteriology (Holt et al., 1994).

\section{Results}

\subsection{Isolation of Protease-Producing Bacteria}

The primarily screening of bacteria for protease enzyme production was confirmed on milk agar medium. Each isolated bacteria culture were spotted on sterile milk agar plate confirmed for proteolytic enzyme production again for further use as indicated in figure 1. This was the first experiment for testing microbes on milk agar medium for protease enzyme production.

The clear zone formation around the bacterial colonies were indicated the protease positive bacteria which might be due to hydrolysis of casein. Cheese samples were analyzed for isolation of proteolytic bacterial cultures as indicated in figure 1 .

As the result revealed that almost all isolated bacteria from cheese food stuff had potential in the production of an enzyme which is a promising study for various activities. Each isolates of bacteria were form a clear zone on milk agar medium through hydrolysis of casein protein that found in milk. Isolate 21 (Iso21) was form the highest clear zone than other isolates as indicate in figure 2 and Table 1. 


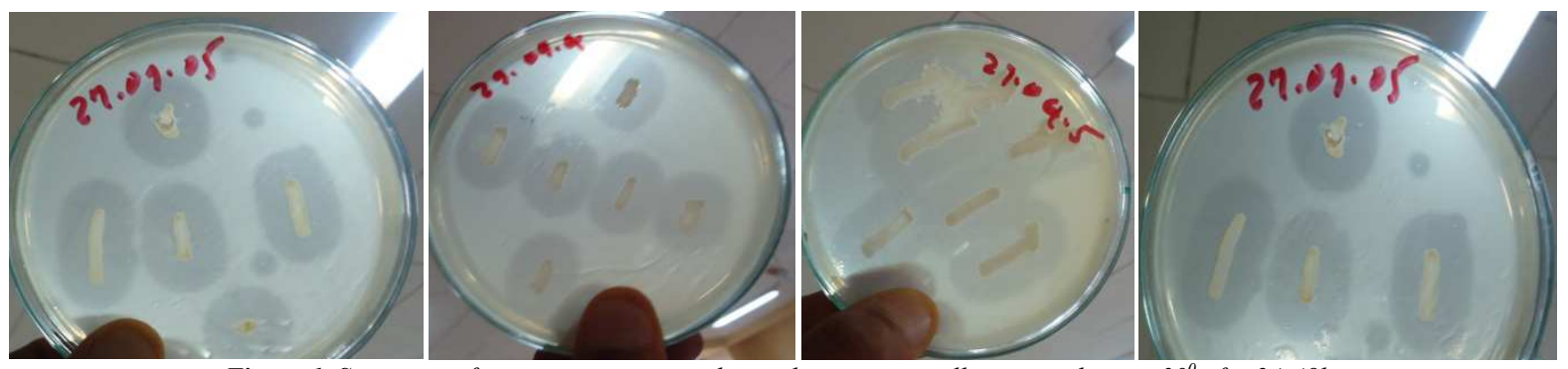

Figure 1. Screening of protease enzyme producing bacteria on milk agar medium at $30^{\circ} \mathrm{c}$ for $24-48 \mathrm{~h}$.
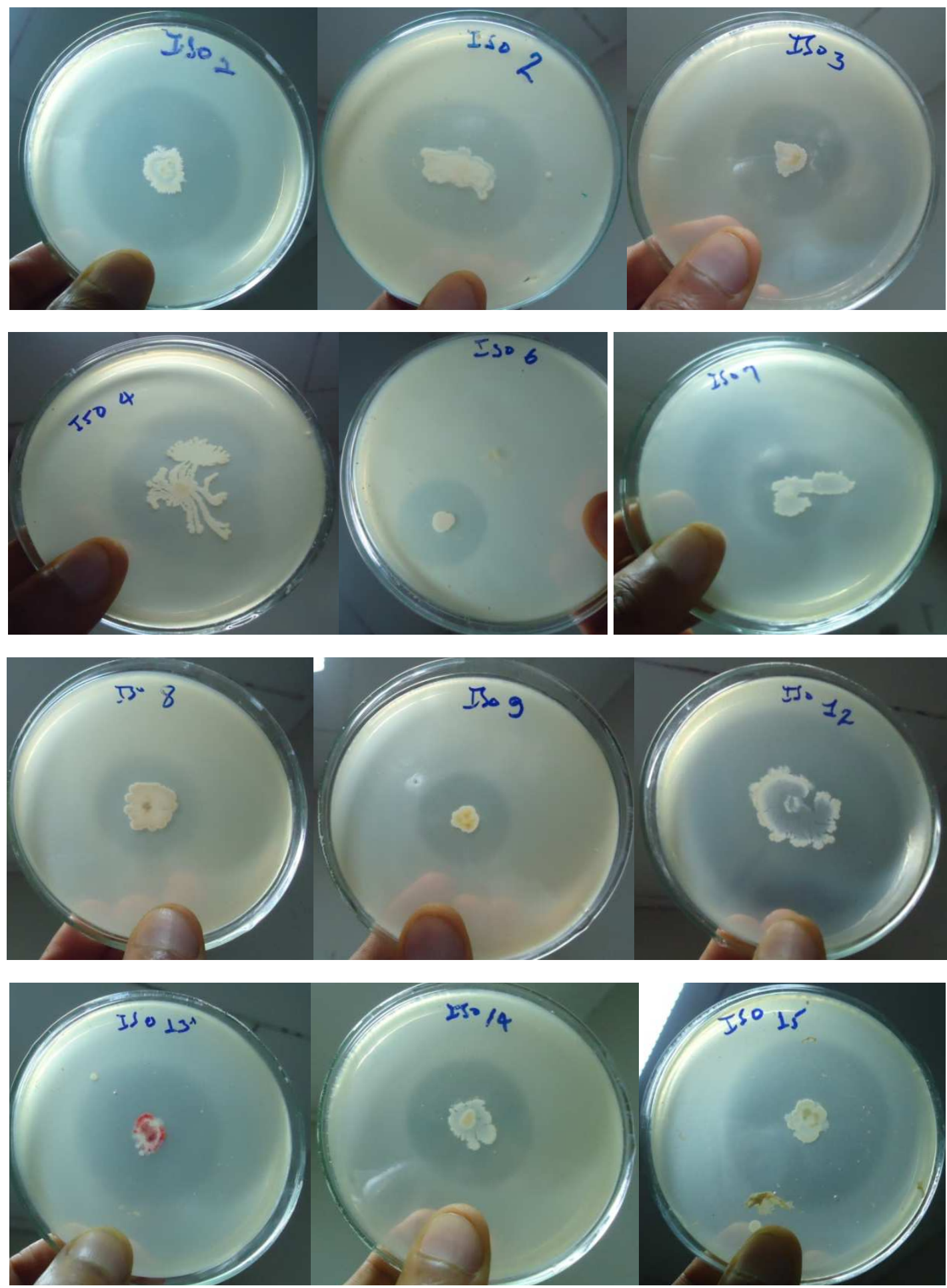

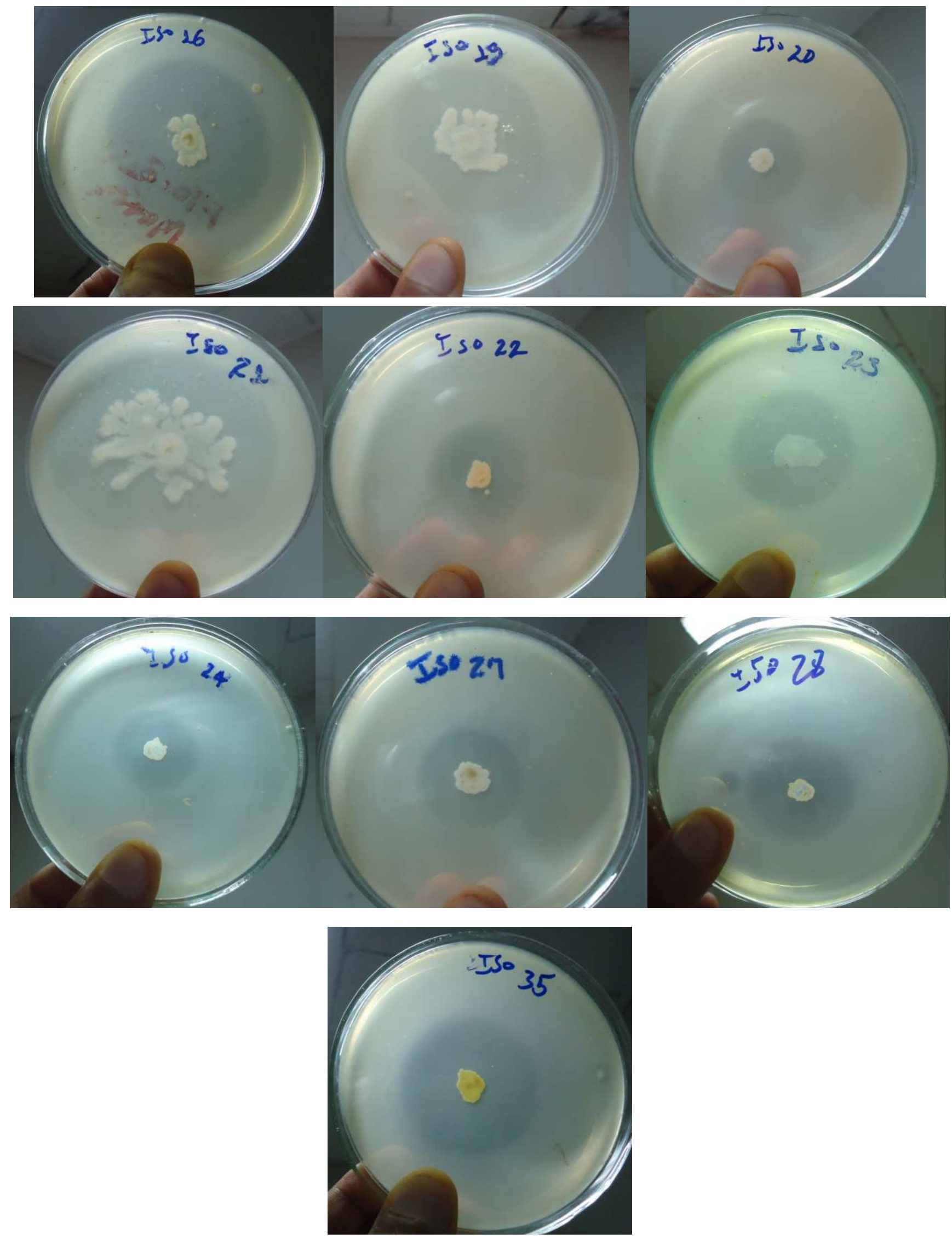

Figure 2. Bacterial isloate forming the clear zone on the milk agar medium at $30^{\circ} \mathrm{c}$ for $48 \mathrm{~h}$. 
Table 1. Isolated bacteria of clear zone and their biochemical characterization on milk agar.

\begin{tabular}{|c|c|c|c|c|c|c|c|}
\hline \multirow{2}{*}{$\begin{array}{l}\text { Screened } \\
\text { bacterial isolates }\end{array}$} & \multirow{2}{*}{$\begin{array}{l}\text { Clean Zone (mm) } \\
\text { (Diameter) }\end{array}$} & \multicolumn{6}{|c|}{ Biochemical characterization } \\
\hline & & Gram staining & Bacterial shape & Catalase & Oxidase & Colony morphology & Pigment \\
\hline Iso1 & 56.80 & - & Rod & + & + & Irregular, Undulated & Light white \\
\hline Iso2 & 55.00 & + & Rod & - & + & Irregular & Light \\
\hline Iso3 & 50.67 & + & Rod & + & - & Irregular & Light \\
\hline Iso4 & 51.67 & - & Cocci & - & - & Irregular, Rhizoid & Light \\
\hline Iso5 & 21.67 & + & Cocci & + & - & Irregular & Light \\
\hline Iso6 & 21.50 & - & Rod & - & - & Circular & Light \\
\hline Iso7 & 35.00 & - & Rod & + & - & Irregular & Light white \\
\hline Iso8 & 25.00 & - & Rod & - & - & Irregular & Light \\
\hline Iso9 & 38.33 & + & Rod & - & + & Irregular & Yellow \\
\hline Iso10 & 31.87 & + & Cocci & + & & Spindle & Light \\
\hline Iso11 & 30.89 & + & Cocci & + & $\overline{+}$ & Filamentous & Light \\
\hline Iso12 & 51.67 & + & Rod & + & + & Irregular & Light white \\
\hline Iso13 & 34.67 & + & Rod & + & + & Circular & Red pink \\
\hline Iso14 & 48.33 & + & Rod & - & + & Irregular & Light white \\
\hline Iso15 & 45.00 & + & Rod & - & + & Irregular & Light \\
\hline Iso16 & 48.67 & + & Rod & - & - & Irregular & Light \\
\hline Iso17 & 24.90 & + & Rod & - & + & Spindle & Light \\
\hline Iso18 & 51.67 & + & Rod & - & + & Irregular & Light \\
\hline Iso19 & 61.67 & + & Rod & + & + & Irregular & Light white \\
\hline Iso20 & 38.33 & - & Cocci & - & + & Circular & Light \\
\hline Iso21 & 66.50 & - & Cocci & - & + & Rhizoid & Light white \\
\hline Iso22 & 35.00 & - & Rod & + & + & Circular & Light \\
\hline Iso23 & 37.33 & - & Rod & + & + & Irregular & Light white \\
\hline Iso24 & 33.33 & + & Rod & - & + & Irregular & Light \\
\hline Iso25 & 26.87 & + & Cocci & + & - & Irregular & Dizzy white \\
\hline Iso26 & 34.08 & + & Cocci & + & - & Irregular & Dizzy pink \\
\hline Iso27 & 50.00 & + & Rod & - & - & Irregular & Light white \\
\hline Iso28 & 46.67 & + & Rod & + & - & Irregular & Dizzy yellow \\
\hline Iso29 & 31.45 & + & Rod & - & + & Irregular & Light \\
\hline Iso30 & 32.54 & + & Cocci & + & + & Circular & Red \\
\hline Iso31 & 31.90 & - & Rod & + & - & Irregular & White \\
\hline Iso32 & 36.98 & - & Rod & + & - & Punctiform & Red \\
\hline Iso33 & 51.67 & + & Cocci & - & + & Irregular & Yellow \\
\hline Iso34 & 34.84 & + & Rod & - & - & Filamentous & White \\
\hline Iso35 & 46.45 & + & Rod & - & + & Circular & Yellow \\
\hline
\end{tabular}

Key: += positive result, - Negative result, $\mathrm{mm}=$ millimeter

\subsection{Discussion}

This result was promising and gives the profitable method for future on this medium to scale up for protease enzyme production. Microbial proteases have a number of commercial applications in industries such as in food, leather, meat processing and cheese making. Enzyme production by micro-organisms is greatly influenced by media components, especially carbon and nitrogen sources, and physical factors such as temperature, $\mathrm{pH}$, and incubation time and inoculums density (Muthulakshmi et al., 2011). It is important to produce the enzyme in inexpensive and optimized media on a large scale for the process to be commercially viable (Muthulakshmi et al., 2011). Agricultural byproducts rich in cellulosic biomass can be exploited as cheap raw material for the industrially important enzymes and chemicals (Bigelow and Wyman, 2004). A major commercial use is the addition of microbial proteases to domestic detergents for the digestion of pertinacious stains of fabrics (Sharma et al., 1980).

Screening of bacteria that produced protease was done on milk agar. The clear zone of casein hydrolysis of bacteria milk protein was an indication of protease secretion. Similar, the clear zone of casein hydrolysis was an indication of protease secretion as reported by Folasade et al. (2005).

Beside of forming clear zone, these isolated bacteria were characterized their pigmentation, catalase and oxidase enzyme production, gram reaction and morphological identification. Haq et al. (2004) have also reported that maximum production of protease by Penicillium griseoroseum was obtained at an incubation temperature of $30^{\circ} \mathrm{C}$ and the enzyme production was reduced when the incubation temperature was increased above $30^{\circ} \mathrm{C}$. Proteases have been employed for the production of dipeptide aspartame, which is a non-caloric artificial sweetener.

\section{Conclusion}

Proteases enzyme have been used in the manufacture of cheese and detergent manufacturing industry for many years. Besides the alkaline proteases are used in leather industry for the removal of hairs and parts which are present on the animal skin. In the pharmaceutical industry, varying and specific proteases are used in developing effective therapeutic agents. Therefore, from this point of view, all 
screened isolate for protease enzyme production certainly offer a great promising result for further use.

\section{Acknowledgements}

The authors greatly acknowledge the Departments of Biology, College of Natural, and Computational Sciences of Dilla University for the kind assistance in providing the laboratory facilities and all the required consumables and equipment during the whole period of these research activities.

\section{References}

[1] Aleksieva P, Peeva L (2000). Investigation of acid protinase biosynthesis by the fungus Humicola Lutea 120-5 in an airlift bioreactor. Enzyme Microb. Technol. 26: 402-405.

[2] Benslimane C, Lebrihi A, Lounes A, Lefebvre G, Germain P (1995). Influnce of dextrins on the assimilation of yeast extract amino acids in culture of Streptomyces ambofaciens producer of spiramycin. Enzyme. Microb. Technol. 17: 10031013.

[3] Bhaskar N, Sudeepa ES, Rashmi HN, Selvi AT (2007). Partial purification and characterization of protease of Bacillus proteolyticus CFR3001 isolated from fish processing waste and its antibacterial activities. Bioresour. Technol. 98: 27582764.

[4] Bigelow P, Wyman E (2004). Production of cellulolytic on bagasse pretreated with chemicals. Applied Biochem. Biotechnol. 102: 78-82.

[5] Burhan A, Nisa U, Gokhan C, Ashabil A, Osmair G (2003). Enzymatic Properties of a novel thermostable thermophilic alkaline and chelator resistant amylase from an alkaphilic Bacillus sp isolate ANT-6. Process Biochemistry (38): 13971403.

[6] Deng A, WU J, Zhang Y, Zhang G, Wen T (2010). Purification and characterization of a surfactant-stable high-alkaline protease from Bacillus spp. B001. Bioresour. Technol. 101: 7100-7116.

[7] Djamel C, Ali T, Nelly C (2009). European journal of Scientific Research. 25(3): 469-477.

[8] Enzyme Technical Association (2001). Enzymes; A primer on use and Benefits today and tomorrow. Washington, DC 200036 pp. 1-32.
[9] Folasade M, Olajuyigbe, Joshua O, Ajele (2005). Production dynamics of extracellular protease from Bacillus species. Afr. J. Biotechnol. 4(8): 776-779.

[10] Gupta R, Beg QK, Khan S, Chauhan B (2002). An overview on fermentation, downstream processing and properties of microbial alkaline proteases. Appl. Microbiol. Biotechnol. 60(4): 381-395.

[11] Gupta R, Beg QK, Lorenz P (2002). Bacterial alkaline proteases: molecular approaches and industrial applications. Appl. Microbiol. Biotechnol. 59: 15-20.

[12] Haq I, Mukhtar ZA, Riaz N (2004). Protease biosynthesis by mutant strain of Penicillium griseoroseum and cheese formation. Pakistan J. Biol. Sci. 7: 1473-1476.

[13] Holt JG, Krieg NR, Sneath PHA, Stately JT, Williams ST (1994). Bergey's manual of determinative bacteriology 9th ed. Williams and Wilkins: Baltimore.

[14] Jellouli K, Bougatef A, Manni L, Agrebi R, Siala R, Younes I, Nasri M (2009). Molecular and biochemical characterization of an extracellular serine-protease from Vibrio etschnikovii. Microbiol. Biotechnol. 36: 939-948.

[15] Muthulakshmi C, Gomathi D, Kumar DG, Ravikumar G, Kalaiselvi M, Uma C (2011). Production, Purification and Characterization of Protease by Aspergillus flavus under Solid State Fermentation. Jordan Journal of Biological Sciences 4(3): 137-148.

[16] Nout MJR, Rombouts FM (1990). Recent developments in tempe research. J. App. Bacterial. 69: 609-633.

[17] Oyeleke SB, Oduwole AA (2009). Production of amylase by bacteria isolated from a cassava dumpsite in minna, Nigerstate, Nigeria. African Journal of Microbiology Research 3(4): 143146.

[18] Pandey A, Soccol CR, Mitchell D (2000). New developments in solid state fermentation. Bioprocesses and products. Proc. Biochem. 35: 1153-1169.

[19] Rao MB, Tanksale AM, Gha MS, Deshpande VV (1998). Molecular and biotechnological aspects of microbial proteases Microbiol. Mol Biol. Reviews 62(3): 597-635.

[20] Sanchez-Porro C, Martın S, Mellado E, Ventosa A (2003). Diversity of moderately halophilic bacteria producing extracellular hydrolytic enzymes. Journal of Applied Microbiology 94(2): 295-300.

[21] Sharma OP, Sharma KD, Nath K (1980). Production of proteolytic enzyme by fungi. Rev. Roum. Biochem. 17: 209215. 